\title{
Kicked To The Curb \\ The triangular trade of neoliberal polity, social insecurity, and penal expulsion
}

\section{Anthony Lloyd and Philip Whitehead}

Teesside University

\begin{abstract}
The slave trade of the 1700 s constituted a triangular trade in human cargo. Critically, there is a contemporary triangular trade, the three limbs of which are neoliberal polity; the reproduction of social insecurity; and the modernised transformation of criminal justice and penal policy in the direction of exclusionary punishment and prison. Additionally, the contemporary triangular trade converges in a double fist of negation: the first is the expulsive consequences of the neoliberal order; the second is the response of the criminal justice domain exemplified in retributive punishment and expanding prison populations. The original and timely contribution of this article juxtaposes the two trades, separated by over three hundred years, to allow the former to reach into the present to advance new insights into the latter.
\end{abstract}

Key Words trade, political economy, insecurity, punishment, prison, expulsion

\section{Introduction}

The purpose and original contribution of this article advances the thesis of a 'triangular trade' in human cargo. In its current manifestation, this trade comprises three overlapping features; firstly, the politico-economic conditions of existence established by the postKeynesian neoliberal turn since the 1980s. Second, contingent upon the neoliberal turn, the reproduction of social insecurity exemplified by the swelling tide of urban outcasts (Wacquant, 2008). Third, the modernisation of criminal justice and penal policy redirected towards punishment and prison expulsion, in marked contrast to the era of penal welfare (Garland, 2001; Home Office, 1977). Strikingly, this trade converges in a vortex of double negation. The first is the bulimic properties of neoliberal capitalism exemplified in the relegated and excluded outcasts of social insecurity (Whitehead, 2018; Young, 2007). The 
second is the reconstituted criminal justice domain with an eroded probation system at one end, and an expanded prison system at the other. We structure the article as follows. First, we refer to an earlier triangular trade in human cargo, namely the slave trade in the $18^{\text {th }}$ century. Whilst our main focus is not on the slave trade per se, it offers an analytical device by which to advance our thesis. The earlier geographic triangular trade in human cargo provides an analytical frame upon which we overlay an existing triadic trade. The slave trade settles our preoccupation within a stream of history and provides an analogy and alternative politico-economic configuration with which to compare our contemporary condition. Second, we sketch the contours of the contemporary triangular trade: a) the neoliberal order; b) the anthropological and socio-ethical consequences of neoliberalism; $c$ ) the modernisation of criminal justice and penal policy. Third, although Wacquant (2001, 2008, 2009a) forges similar linkages, our vital contribution extrapolates similarities and differences associated with the earlier slave trade to enhance understanding of what is a salient contemporary social fact. This is the original feature of our article. While the original triangular trade concerned the movement of productive bodies, the contemporary trade dispatches unproductive and unruly bodies. We think that the juxtaposition and comparison of earlier and contemporary triangular trades opens space to advance new insights and critical analysis to re-work the terms of current debates. This article focuses primarily on England and Wales and the United States, but also alludes to other countries and jurisdictions. It is necessary to begin with a brief excursus into the triangular slave trade.

\section{The colonial trade}

Although slavery had existed for millennia, England's involvement expanded rapidly during the 1700s which fostered colonial expansion in the Americas. Profitable commercial business was supported by the ports of Bristol, Liverpool and London, as well as Whitehaven, Lancaster and Chester. Ships laden with guns, brandy, shells and cloths were exchanged for human cargo destined for the colonies on the East coast of America and Caribbean islands, before returning to England carrying sugar, rum and tobacco. Between 1728 and 1732 Bristol sent 50 ships annually to the slave harbours on the West coast of Africa, transporting 100,000 slaves; by 1740 Liverpool was sending 33 ships a year (Thomas, 1997). Liverpool's geographic proximity to Manchester, the conduit for the Lancashire 
cotton industry (Riello, 2013) ensured that textiles became an important trading commodity in exchange for slaves. Therefore if 'Athens had slaves with which to build the Parthenon, and Rome to maintain the aqueducts, why should modern Europe hesitate to have slaves to build its new world in America' (Thomas, 1997: 795). The trade turned a profit on each triangular transaction (Morris, 1979a: 28) which conflated trade and exchange, buying and selling, with inhumane practices on an industrial scale to fuel economic expansion. As asserted by Ackroyd (2016: 256), 'the slaves were part of the engine of trade'.

Between 1780 and 1790 (Thomas, 1997: 284) approximately 750,000 slaves were carried across the middle passage of the Atlantic. African labour constituted a compliant workforce of productive bodies, adaptable to extreme climatic conditions and capable of relentless graft in the cultivation of sugar (Parker, 2011), coffee, the demands of cotton plantations, and mining (Baptist, 2016).Thomas (1997, appendix 3) assimilates collated evidence to show that 12,000 voyages from Britain resulted in the transportation of $2,600,000$ slaves. The total European slave trade saw 13,000,000 leave African ports as those productive and profitable bodies from Sierra Leone, Windward coast, Ivory coast, Gold coast, Benin, Cameroon, Gabon, Congo, Angola, Mozambique and Madagascar were delivered to Brazil, British North America, Cuba, British West Indies, French West Indies, Dutch West Indies, and Europe. While European states supported and facilitated this trade, slave labour was procured with the compliance of African monarchs, for whom rival tribes constituted the unruly and unproductive (Thomas, 1997; Rediker, 2008). For European merchants, these unproductive bodies represented the exact opposite. At the same time that England expanded its trade in productive human cargo, it engaged in a parallel expulsion of unruly bodies; the transportation of convicts to America and Australia. In those circumstances, unruly bodies represented productive labour and generated value for the ruling elites. Finally, the trade in productive bodies continued within the destination territories as slaves were sold and resold according to demand, need and market fluctuation (Baptist, 2016); the transportation of human cargo proved lucrative.

\subsection{Towards abolition}

Opposition to the trade surfaced in the $16^{\text {th }}$ century (Thomas, 1997), long before it was abolished in England during the early 19 th century. In the 1760s the Quakers agitated 
against the slave trade, so too the Methodists under Wesley (Merrill, 1945). However, in 1789 William Wilberforce began one of the 'greatest parliamentary struggles' (Hague, 2008: 175) as his call for abolition commenced a 20 year battle. Opposition to slavery gathered pace and efficacy and came from a variety of sources including increased public awareness into the practice; religious values of compassion mingled with Enlightenment moral philosophy which advocated equality; inchoate newspaper communications; petitions; and parliamentary opposition (Merrill, 1945; Drescher, 1994). In other words an admixture of philanthropy, morality, philosophy, evangelical theology, the dialectic of political opposition, and humane sensibilities coalesced to bolster opposition both within and beyond parliament. By contrast, forces resisting abolition mobilised a rearguard action, primarily because it threatened the vested interests of ship owners, commercial trades in Liverpool and Bristol, manufacturers of goods exported to Africa from the growing industrial towns, and owners of plantations in the West Indies where slavery was the foundation of wealth (Eltis and Engerman, 2000).

Despite growing opposition, the trade continued to flourish (Hague, 2008: 292). Thirteen years after the abolition committee first convened in London and eight years after half a million people petitioned parliament to abolish slavery, it was thriving. Between 1791 and 1800, 400,000 African slaves were trafficked to America. In 1792, 204 slave ships left the UK, the most in a single year, whilst $1798-1802$ represents the five year period with the most slave ship departures (Eltis and Engerman, 2000). The profitable trade in commodities reproduced on the back of a slave-based economy proved hard to interrupt. When abolition finally arrived it was not primarily because of Eric Williams' (1964) thesis - the decline of British economic interests following the American Revolution of 1776 - rather due weight should be awarded to the appeal of moral conviction (Thomas, 1997: 494). However, the 1807 Abolition Act did not end the practice; in 1807 the Atlantic slave trade continued (van der Linden, 2010). Furthermore, as van der Linden (2010) notes, the abolitionist movement targeted the slave trade, not slavery itself. The internal slave trade in the US continued until Emancipation in the 1860s (Baptist, 2016), whilst slavery itself was not fully abolished; the $13^{\text {th }}$ Amendment to the US constitution continues to permit slavery for those convicted of offences (Blackmon, 2009). Finally, the global spotlight on 'modern slavery' demonstrates the continuation of the practice today (UNODC, 2016). The colonial 
trade in productive bodies establishes an analytical platform to advance our central thesis of a contemporary triangular trade, to which we now turn.

\section{The contemporary trade}

Having identified an earlier triangular trade, with clear consequences for trade, profit, and human bodies, this section will outline a contemporary triangulation between neoliberal political economy, its consequences in relation to marginality, insecurity and inequality, and the retooled penal response. In doing so, this presents an opportunity to compare and contrast past and present. The analytical waters are somewhat murky; a strand of US criminal justice literature identifies a continuum between our first example and second, namely the continuation of forms of state control over African American bodies from slavery, through Jim Crow, to the ghetto and prison (Wacquant, 2001; Blackmon, 2009; Thompson, 2010; Alexander, 2011; Hinton, 2016). The analytical framework employed here exists at the level of political economy yet, as discussed below, identifies and acknowledges the racial component.

\subsection{Neoliberal dispensation - a brief excursus}

From the excavation of its philosophical foundations (Gane, 2015), impact upon economic and political decisions (Harvey, 2005; Mirowski, 2013), reconfiguration of civic and institutional life (Lloyd, 2013; Whitehead, 2016; Winlow and Hall, 2013), to its flaws, limitations and survival following the 2008 financial crisis (Harvey, 2010; Streeck, 2016), neoliberalism has been a dominant factor in academic debate for decades. Ontologically it supports the rational subject capable of co-operation and mutual self-interest. At the level of political ideology and economic practice it advocates the primacy of freedom for market forces and individual actors, the legitimacy of private property, and unfettered competition. Market economies rely on stability often formed through monopoly and cartels rather than unlimited competition, demonstrating dissonance between ideology and reality (Dean, 2009). Accordingly, Harvey (2005) and Badiou (2007) see the neoliberal order as a class project which restores elements of classical liberal ideology and propels neoliberal elites to their 'rightful' place at the apotheosis of the social pyramid. 
With reference to criminal justice, Harcourt (2006; 2009) suggests that neoliberalism and its quest for 'market efficiency' today is akin to the 'natural order' of $18^{\text {th }}$ century philosophers. The idea of freedom in market or economic transactions dates back to classical liberalism and thus negates the claim that neoliberalism represents something 'new'. However, as Harcourt himself acknowledges (2009), the state has a more activist role under neoliberalism. Rather than the erosion of the nation-state in an era of globalisation and a return to 'laissez-faire' through deregulation (Mirowski, 2013), neoliberalism is, for some, a project intimately connected to the role and function of the state (Mitchell and Fazi, 2017; Harvey, 2010). A recalibration of the state and its primary functions is evidenced in Wacquant's (2009a: 8) 'liberal-paternalist' political regime; liberal and permissive for Harvey's 'capitalist class' yet paternalist and authoritarian for those 'caught between the restructuring of employment and the ebbing of social protection'. For Wacquant (2009a), neoliberalism represents a transnational political project aimed at reforming the nexus of market, state and citizenship. Since the 1970s, neoliberal restructuring of state, market and civil society along the lines of Mises, Hayek, Rand and Friedman endorsed a politicoeconomic transformation which systematically transferred assets from the many to the few and culminated in the 2008 crash and subsequent 'consolidated state' response (Streeck, 2016).

The core mechanism of the market has colonised many areas of civic and social life (Sorman, 2010), transforming a market economy into a market society in such a way that the thermostatic regulatory valves of Keynesian polity was unable to withstand (Piketty, 2014). The marauding skirmishes of free market policies and deindustrialisation, deregulation, privatisation and financialisation (Harvey, 2005; Miller, 2010) with minimal oversight and maximal freedom for capital, generated a wealth explosion for the few and envy amongst the many. Rather than offering redress to inequality or insecurity, the neoliberal order dangled the tantalising prospect to maximise Weber's 'market share' and join society's winners by competing in the meritocratic race to the top. This demonstrated not only neoliberalism as the dominant form of political economy but its ideological ascension as normative within Western societies. The priority of markets over morals, economics over ethics (Sandel, 2012; Whitehead, 2015a) undermined the production of stable ethico-social relations between subjects and corresponding obligations towards each other (Smith and 
Raymen, 2016; Lloyd, 2018a), constitutive of post-social arrangements (Baudrillard, 2007). In other words, neoliberal ideology and its accompanying economic practices produce bulimic effects. But the reconfiguration of the state-market-citizen triad, accompanied by the re-formation of human subjectivity, is not without consequences.

\subsection{Anthropological and social consequences}

The adherence to neoliberal polity systematically unravels the role of the state in providing a social safety net (MacLeavy, 2010). As the state recalibrates around the needs of capital and public institutions increasingly adopt market principles, neoliberal reforms deregulate and reregulate government provision to reduce costs and maximise profit margins. The global financial expansion and subsequent legal frameworks to support the movement of capital across borders impact upon national, regional and local economies subject to the vagaries of the market (Varoufakis, 2013). The emphasis on productivity, profitability and efficiency negatively affect labour markets which shift from the relatively secure to the threateningly flexible (Lloyd, 2018a; 2018b). Flexible labour and the erosion of employment protection create instability when secure employment conditions are removed through competition (Lloyd, 2013). Correspondingly debt levels rise as individuals and families buttress depressed wages and the indeterminacy of unemployment, zero-hour and temporary contracts with credit whilst, as consumers, the demand for display and status through commodities and 'experiences' to offset the inconsequentiality of working life assumes greater significance (Hall et al,. 2008; Horsley, 2015). As Wilkinson and Pickett (2009) noted, inequality generates negative outcomes across a range of measures, including health, education and life expectancy. Inequality is an intrinsic quality of neoliberalism (Mirowski, 2013); the competitive divide between society's 'winners' and 'losers' raise the spectre of loss and insecurity and moves it to the centre of daily life.

As social solidarity and mutual co-operation are destabilised by a thousand cuts; fear, insecurity and crime destabilise community life (Ellis, 2016; Wilson, 1997). A rich vein of criminological research highlight the impact on communities when work disappears, crime and drug markets proliferate, and criminal justice assumes an authoritarian mantle rather than rehabilitative inclusion (Alexander, 2011; Anderson, 2000; Bourgois, 1995; Wacquant, 2008; Wilson, 1997). There is some debate amongst scholars that questions the 
foundational role neoliberalism plays in social insecurity, instead suggesting that urban unrest, crime and violence, economic insecurity and racial tension presented prior to the neoliberal turn in the 1970s (Hinton, 2016; Thompson, 2010). However, it is clear from the research that inequality and insecurity are central components of neoliberal polity.

Neoliberalism's challenge of securing individual and market freedom has restructured the contours of social existence to generate insecurity which persistently threatens social cohesion. These troubling insecurities exacerbate a situation whereby large swathes of the populace within Western neoliberal societies are increasingly rendered surplus to requirements. Refugees, asylum seekers and migrants are obvious examples (Zizek, 2016) but in an economy without the need for massed workforces, the neoliberal dispensation ensures that marginalised outcasts stalk the earth in greater numbers. As Streeck (2016) argues, the triumvirate of declining growth, growing inequality, and rising debt combine in a deadly embrace of expulsion as neoliberal capitalism cannot guarantee inclusion for all citizens; 'in summary, capitalism, as a social order held together by the promise of boundless collective progress, is in critical condition' (2016: 72).

This is the second limb of the contemporary triangular trade. It also represents the first negation of expulsion from politico-economic organisation, contingent upon neoliberal polity. Additionally, an increasing number of those rendered surplus to requirements are subject to more expansive and expulsive criminal justice regimes.

\subsection{The modernised criminal justice response}

This is the third limb of the contemporary trade which targets mainly the powerless lower down the slope of the socio-economic hierarchy (Sim, 2009: 116; Wacquant, 2008; Wilkinson and Pickett, 2009). The gravitational pull of the expanded criminal justice system represents a second negation, following the grip of social insecurity and marginality. The deeper penetration of the tightly clenched penal fist forms the expressive (Durkheim) and functional (Marx) components of the bulimic response, illustrated by recourse to England and Wales and the United States. It is problematic to forge a seamless triadic relation between the displacement of Keynesian social democracy, the transition towards neoliberalism, urban outcasts, and decisions by the political class to bolster the criminal 
justice backlash. But this is the real effect of political interventions and policy changes which have accumulated over recent decades. The contours of this transition established new conditions of existence which can be further exemplified in the break-up of the postwar settlement in the crisis decade of the 1970s, accompanying economic dislocation, rising crime, growing disenchantment with welfare, treatment, and rehabilitation, culminating in the drift towards law and order, punishment and prison. Under these conditions it is easier to scapegoat and essentialise the excluded other and retaliate through redirecting criminal justice in a penal direction (Young, 1999 and 2007; Whitehead, 2018). The way things turned out is different to how things operated for several decades after 1945 (Home Office, 1977). In fact, the direction of travel prior to the 1970s had been towards a reduction in prison numbers before an abrupt reversal and the journey towards mass incarceration (Simon, 2000; Tonry, 1999; Hinton, 2016; Millie et al, 2003).

Wacquant (2008, 2009a, 2009b) forges theoretical and empirical, political and policy linkages between neoliberal ideology, social insecurity, and the penalisation of poverty. If the neoliberal order has been imposed from above, cascading structural violence to destabilise the post-war consensus, this has been shored up by criminal justice reforms. We have witnessed the erosion of a probation culture which acted as a cordon sanitaire against excessive punishment and exclusion. Probation services at their best offered welfare and inclusivist rehabilitation within the dialectics of criminal justice (Home Office, 1977; Whitehead and Crawshaw, 2013). What is more the screw is countersunk on the tripartite trade to exacerbate the exclusionary cycle following release from prison (Prison Reform Trust, 2016; Whitehead, 2011). Many prisoners are released back into conditions of social insecurity. As Padfield and Maruna (2006) indicate, the absence of effective aftercare and resettlement provision is partly responsible for the significant growth in prison recalls; offenders released on licence appear to breach the conditions of parole more frequently and are returned to prison. When prisoners are released back into conditions of social insecurity and precarity, without adequate provision or support, staying out of prison becomes difficult. No amount of well-intentioned prison reform, tinkering with the internal bureaucratic mechanisms of prison regimes, ceding more freedom to prison governors, will remedy the problem it seeks to address (Truss, 2017). If Currie (2010) suggests that the prison 'problem' can only be resolved through thorough investigation of the 'crime 
problem', we go further to suggest that problems facing UK and US prison regimes are intimately entwined with a wider contemplation of the 'social insecurity problem'. The contemporary tripartite trade in bodies and its reproductive cycle is responsible for wasted lives as the first negation (Bauman, 2004), followed by the second negation of criminal justice exclusion.

Parenti (1999) analysed criminal justice and penal policy in the United States. He argued, as did Wacquant a decade later, that the upsizing of the criminal justice estate constitutes a rational response by the governing class to economic restructuring. Those reclassified as 'social junk', tempest-tossed victims of deregulated market forces are treated to zerotolerance policing to sanitise the streets. Squatters, alcoholics, the mentally ill, drug addicts, and the homeless are candidates for criminalisation or removal from the public gaze. Wacquant (2001) draws a line from slavery, through the Jim Crow laws of reconstruction, to the ghetto and, under conditions of neoliberalism, the hyperghetto and a 'deadly symbiosis' between the ghetto and prison. The socio-ethnic cleavages of US criminal justice are evident in the figures (see below) and the literature (Thompson, 2010; Hinton, 2016). Although Harcourt $(2006 ; 2011)$ notes that the US has always institutionalised problematic populations, initially through mental health facilities until deinstitutionalisation in the 1960s and 1970s, later through mass incarceration, the demographic makeup of the prison system represents a clear difference to previous forms of institutionalisation. As the welfare arm of the state contracts, social insecurity rises and the carceral arm of the state steps in (Wacquant, 2009a). The militarisation of police forces represents a determination to secure urban space and clear prime real estate from socially undesirable outcasts (Graham, 2011), thus effectively criminalising space inhabited by those lowest on the slopes of socioeconomic hierarchy (Thompson, 2010). Furthermore, the securitisation of US schools, in response to the dangers presented by urban outcasts, retools the 'schoolhouse' as 'jailhouse' (Fuentes, 2011). Thomas Mathiesen (1974 and 2015) draws attention to the expurgatory function of prison and Jeffrey Rieman (1998) notes how the rich get richer whilst the poor get prison.

In 2000 the worldwide prison population was 8.7 million, now currently around 10.4 million (Coyle et al., 2016: 37). The four countries, in absolute numbers, that imprisons the most 
are the USA, China, Russia and Brazil. In the United States there has been a rapid rise since the 1970s, reaching half a million by 1980, passing 2 million by 2000 before reaching a high of 2.3 million by 2008 . The rate imprisoned per 100,000 of the population hover around 698. Additionally there is a racial disparity in the United States' prison system. In December $2014,6 \%$, or 1 in 17 , of all 30-39 year old black men were in prison compared to $2 \%$ Hispanic and $1 \%$ white men of the same age group. This growth is explained by political initiatives, policy decisions, response to rising crime, punitive sentencing for drugs, and the introduction of mandatory minimum terms (Coyle et al., 2016: 46; also Alexander, 2011; Dagan and Teles, 2016). The Crime Omnibus Act (1993) and Violent Crime Control and Law Enforcement Act (1994) strengthened the penal arm before the 'reformation' of public welfare through the abolition of Aid to Families with Dependent Children (AFDC) and the passage of the Personal Responsibility and Work Opportunity Act (PROWA) (Wacquant, 2009a). Dagan and Teles (2016) suggest that mass incarceration could be under threat (see also Simon, 2014) as conservatives increasingly recognise fiscal, moral and religious critiques of mass incarceration. However, despite the Obama administration's Sentencing Reform and Corrections Act reducing mandatory minimum sentences, the penal state remains intact and looks set to expand under the Trump administration.

In England and Wales, the spike in the prison population occurred after 1992/93 following a period of relative stability. Critical aspects of the 1991 Criminal Justice Act, including the intention to suppress the prison population, were unpicked by the retaliatory 1993 Act. Between 1993 and 2012 the prison population almost doubled from 45,000 to 87,000, with a corresponding rate increase to 153 per 100,000 of the population. A higher proportion of convicted offenders were sentenced to custody and for longer (Carter, 2007), in addition to a higher rate of recall to prison. In England and Wales, black, Asian, and minority ethnic individuals make up $14 \%$ of the population but over $25 \%$ of the prison population (Coyle et al., 2016: 114). Hall et al (1978) note the racial component associated with law and order narratives of the 1970s, particularly the concern over black men and street crime. Whilst eschewing Hall et al's 'moral panic' thesis (see Horsley, 2017) and the 'crisis of legitimacy' that underpins this analysis, the UK prison figures demonstrate a clear class and racial disparity. If it can be empirically verified that different socio-economic groupings are not evenly represented in the composition of prison population, this also applies to racial 
composition. In addition to the United States, England and Wales, a disproportionate number of prisoners in New Zealand and Australia are from minority groups. Rodger (2008) adds to the discussion on the criminalisation, relegation, and exclusion of the demonised other explicable within the politico-economic context of the neoliberal turn. In fact, the prison system since 1992/93 which incorporates Conservative, New Labour and coalition administrations has been transformed into a "key institution in the reformulation of social control practices' (Sim, 2009: 128) targeted at a specific section of the population.

Since the reversal of the 1991 Criminal Justice Act; the custodial turn of the Major-Howard axis of 1992-93; New Labour consolidation 1997-2010; the Conservative-Liberal alliance 2010-2015; and the Conservative government proposals for reform in the Prison and Courts Bill that surfaced prior to the general election of June 2017 (Truss, 2017); criminal justice has maintained its punitive market share whilst simultaneously infusing its services with the business principles of efficiency, productivity and targets (see Whitehead, 2015a; 2015b; 2016). Despite periodic pronouncements relating to tackling social exclusion and a 'rehabilitative revolution', the direction within the system has remained more punitively exclusionary than rehabilitatively inclusionary.

The next step fuses together the colonial slave trade and contemporary triangular trade. This final section will compare and contrast key features of both trades to advance new analytical insights into the latter.

\section{When two trades go to war}

\subsection{Productive v. Unproductive Bodies}

The designation of productive and unproductive bodies has been assembled under two contingent politico-economic structures. Although the distribution of bodies in these two eras is separated by over 300 years, both constitute triangular trades. The slave trade functioned as a commercial enterprise in pursuit of profit which was achieved on each transaction. Putting bodies to work to extract maximum labour power fuelled the engine of colonial trade which linked three determinate points on the geographical compass. It should also be noted that trade and the profit motive persisted in the transition from the first to second empires, turning from West to East, the Americas to India in the $19^{\text {th }}$ century. 
This second empire trade, like the earlier colonial slave trade, depended on productive bodies (Morris, 1979b: 99). Whilst the politico-economic structure of the slave trade relied upon productive bodies, the complicit African rulers and monarchs who provided human cargo at a price deemed these commodities unruly and surplus to requirements. What was deemed productive labour for the slave traders was unproductive and problematic for others. This corresponds with the UK's own policy that jettisoned unruly and dangerous bodies via the deportation of prisoners to Australia, although these unruly individuals were put to work as productive labour upon their arrival.

Three hundred years later, the contemporary triangular trade is immured in the reproduction, management, containment and punitive exclusion of unproductive bodies ${ }^{1}$. The political economy of neoliberal financial capitalism creates the conditions of existence to render human bodies surplus to requirements. These are bodies to which the appellation human waste, marginalised, and troublesome has been appended. Ideologically and economically-driven decisions made at, and imposed from, the upper reaches of the sociosymbolic ladder deposit adverse effects as they tumble with gathering speed towards the bottom of the slope. The two limbs of the neoliberal order and its socio-economic effects create the conditions in which the third limb of the criminal justice system is systematically reconfigured in the direction of punitive exclusion in an expanded prison system (Bell, 2011; Garland, 2001; Reiner, 2007; Wacquant, 2009a and 2009b).

Thompson (2010; 2012) notes the prison-industrial complex undermines legitimate labour markets and union efforts through the use of prison labour, for example to tackle California's wild fires (Nekalson, 2017). In effect, this makes these bodies productive but only in the sense that the prison-industrial complex puts to work, at vastly reduced costs, those who are deemed unproductive in the formal economy and jettisoned accordingly. These three components are soldered together to assemble a triangular trade that produces a double negation of expulsion; it constitutes a new social fact. Stated differently, the two

\footnotetext{
${ }^{1}$ Note of qualification: The prison industrial complex appertaining mainly to the United States draws attention to capital investment and markets expanding into the criminal justice domain in search of profit generation. The private sector is also involved in some prisons in England and Wales, in addition to a mixed economy of community provision after October 2014 in Community Rehabilitation Companies (see Goldberg and Evans, 2003; also Whitehead, 2016: pp22-32).
} 
trades represent the transition from the reproduction of surplus value to the reproduction of bodies rendered surplus to requirements.

\subsection{Racial v. socio-economic expulsion but with a persistent racial tinge}

The triangular trade of the 1700s constructed, operated, and maintained by white Europeans, exported and reassigned the status of a racial group of black Africans through enslavement in the Americas. Furthermore, African monarchs, indigenous noblemen and the merchant class were complicit in what was a lucrative business. Although the trade was abolished in 1807 in England there is a persistent racial tinge to the contemporary trade manifested in the differential responses to, and practices of, the criminal justice system in the United States, United Kingdom, as well as other countries (Coyle et al., 2016; Hinton, 2016; Alexander, 2011). In the main, criminal justice systems enfold within their institutional grasp the socio-economically disadvantaged. Illustratively, Coyle et al. state that 'prisons as they exist today are a reminder of nineteenth-century social philosophy which constructed large, secure institutions to hold people who were at the margins of society: poorhouses, mental institutions, orphanages and prisons' (2016: 135). The marginalised are produced by, then immured into, unpropitious socio-economic circumstances and bear the lesions of disability, learning difficulties, mental health affliction, alcohol and drug addiction, lack of education and skills, housing and employment disadvantages.

Additionally, and disturbingly, criminal justice practices continue to betray a racial tinge as ethnic minorities are disproportionately represented in a number of jurisdictions from the United States and England and Wales, to New Zealand, Australia and Canada. Wacquant (2009b: 156) confirms that 'controlling for prior record, seriousness of offence, and for indirect effects of race, blacks are more likely to receive a sanction of penal confinement than whites'. It is crucial to note the class and racial composition of prisons across a number of countries. The US literature often draws a line from slavery to mass incarceration (Alexander, 2011; Wacquant, 2001) and theorises a number of consistent 'peculiar institutions' designed to control and regulate African American lives. Undoubtedly, US penal policy betrays long-standing socio-cultural dimensions related to race and the lineage of slavery, Jim Crow and the ghetto continues in the guise of hyper-incarceration. However, 
the comparative analysis shows that racial and class disparities exist across numerous countries. The triangular slave trade may well have been abolished in 1807 in England, but socio-economic status, class position, and race congeal in the contemporary trade in human cargo.

\subsection{Traversing the middle passage v. contemporary trading arrangements}

We have returned to the slave trade as the surface upon which to foreground those features that comprise the contemporary trade in human cargo, from political economy, to criminal justice and penal policy. Here two aqueous cultural representations can be introduced to personify the movement of bodies within both trades. The first trade was notorious for its middle passage when transporting and disposing bodies across the Atlantic. Joseph Mallord William Turner's painting originally called Slavers throwing overboard the Dead and the Dying - Typhoon Coming on was first exhibited at the Royal Academy in 1840, after the trade was abolished in 1807 . This striking yet disturbing picture captures an incident when the Liverpool slave ship Zong sailed from the African coast in September 1781 with 442 slaves (Lewis, 2007) ${ }^{2}$. Subsequently, it found itself low on drinking water, compounded by navigational errors, which culminated in casting overboard 133 African slaves. Turner's painting depicts the Zong slicing through turbulent waves and depositing bodies into the sea. The painting was revered by some but others were less persuaded by its merits (Ackroyd, 2006: 137). In this example, human cargo is literally expelled into turbulent water. If we persist metaphorically, the neoliberal project jettisons bodies into the turbulent waters of social insecurity, some of whom are snagged by the criminal justice apparatus. We can graft onto Turner's image Cohen's (1985: 236) graphic reference to Saul Alinsky's parable of bodies being observed floating down river to be rescued one by one. Rather than rescue these bodies as they float by, someone should walk upstream to locate the cause of the problem; where and why are they being thrown into the river? At first sight, Turner's painting with its vibrant colours offers much to the eye, as does the tantalising prospect of neoliberal capitalism's promise of opportunity, mobility, success and

\footnotetext{
2 The Zong incident ostensibly occurred to protect the safety of the remaining passengers and crew, but was motivated to ensure that the ship owners would not incur a financial loss. When the insurance claim was made to compensate the owners the insurance company refused to pay and a court case followed: Gregson $v$ Gilbert 1783. The court ruled against the owners' claim based on evidence that the captain and crew were at fault (see Lewis, 2007). Significantly, the Zong incident was instrumental in the abolition movement.
} 
status. But look with care and it is possible to detect deposited bodies, floating by or sinking, jettisoned by forces legitimised and normalised. What is more, the criminal justice system is lying in wait to snag bodies before releasing them again into the unpropitious waters of the contemporary triangular trade. These factors constitute current internal trading arrangements. The bulimic turbulence of the neoliberal order ejects its surplus human casualties into the turbulent waters of social insecurity, compounded by the transformed criminal justice response.

\subsection{Historic v. contemporary collusion in the triangular trade}

There were those who supported, actively collaborated and colluded with the triangular slave trade. Equally, others opposed the trade which eventually culminated in abolition, a theme we return to below. For those who colluded in the slave trade during the $1700 \mathrm{~s}$, it was indubitably in their financial interests to do so (Eltis and Engerman, 2000). Ship owners; the ports of Liverpool, Bristol, Whitehaven, Lancaster, and Chester; subsidiary trades associated with ship building; manufacturers of exported goods, traded and exchanged for human cargo in Africa; the Lancashire cotton industry; plantation owners in the Americas involved in the production of raw cotton, rum, sugar, and tobacco. These interrelated factors formed an intricate and expansive network which facilitated and reproduced the spiral of collusion. Some of these vested interests were directly aware of the effects of trade in human cargo in England and the Americas. Others, the consumers of slave products, inadvertently and unwittingly colluded with and reproduced the triangular trade. An existential decision to collaborate with or resist the slave trade became a pressing necessity, which also applies to current trading arrangements.

There is active collaboration with, and collusion in, the contemporary triangular trade. The current trade has been stoked by successive governments since the 1980s in establishing the conditions of existence under which it is reproduced. These governments Conservative, Labour, and Liberal Democrat, Republican and Democrat - have been content to live with the casualties induced by neoliberal insecurity, and criminal justice reforms: the heightening of emotive punitive impulses released to tumble down towards the lower slopes, expansion of prison regimes, and the cultural erosion, and privatisation, of probation (Whitehead, 2016). The contemporary triangular trade is facilitated by intricate webs 
enfolded within reproductive circuits from government to media, public perceptions and responses, legislative inflation, sentencing framework and sentence perceptions, overt political influence and the murky practices of electoral politics (see Hough et al., 2003). Private providers of criminal justice functions and apparatus also collude in search of market share and profit, as do local and regional political leaders who seek investment and criminal justice employment opportunities in locales ravaged by the first strike of neoliberal expulsion, economic and social insecurity. This collusive trade must be interrupted to transform the current situation.

\subsection{The process of abolition}

Let's begin with a solemn declaration: 'The one imperial achievement that gave satisfaction to everybody was the ending of the slave trade...' (Morris, 1979b: 512). As we saw earlier there were multiple sources of opposition which included heightened sensibilities; consciousness-raising; compassion mingled with Enlightenment moral philosophy on equality and the 'rights of man'; inchoate newspaper communications; petitions; and parliamentary opposition (Merrill, 1945; Thomas, 1997). In other words a rich confection of philanthropy, morality, philosophy, religion in the form of evangelical Christianity, politics, ideology, and humanity swelled the forces of opposition within and beyond the parliamentary system. Furthermore, abolition was achieved during a tumultuous political era - French revolutionary fervour, descent into terror, the Bonaparte menace, threat of invasion, and national anxiety associated with Trafalgar 1805 and Waterloo 1815. In other words, abolition was debated and achieved in unpropitious circumstances. Furthermore, it is of academic interest to contrast the process of abolishing the slave trade with the Foucauldian thesis on the birth of the prison (1977). Rather than interpreting the emergence of the disciplinary timetable as a humane gesture prosecuted by reformers, Foucault detects a cunning tactical strategy in the exercise of political power by a dominant group over a subordinate group. According to Foucault the prison is a system of power and regulation in the construction of docile bodies, contingent upon the requirements of $19^{\text {th }}$ century industrial capitalism ${ }^{3}$. The transition from body to soul, the physical torments of the

\footnotetext{
${ }^{3}$ Eric Williams (1964) Capitalism and Slavery connected the slave trade to the rise of capitalism. He also argued that abolition was linked to a decline in economic trading activity in the Americas. In other words, applying greater weight to economic factors than humanitarian reforming impulses.
} 
scaffold to prison, excluded noble impulses and ethical commitments, religious sensibilities, and humane gestures towards the other. These reforming gestures were nothing more than incidental music accompanying the politics of power (Garland, 1990: 168). By contrast, the human drama of abolishing the slave trade contests the Foucauldian dystopian analysis. Accordingly, if the objective is to transform political economy and unmodernise the criminal justice system to reduce the prison population and reliance on punitive impulses, this will require alliances of opposition inside and outside parliament stimulated by philanthropy, moral philosophy, theology, politics, ideology, and foundational expressions of concern for the other. These must be organised to reignite dialectical contestation and the moral responsibility of politics.

\subsection{Further note on the contemporary trade in human cargo}

The abolition of chattel slavery and legal ownership, the dominant relation during the first triangular trade, did not prevent the continuation of other forms of indentured servitude, 'unfree labour' or debt bondage (Thompson, 2010). The $13^{\text {th }}$ Amendment to the US constitution specifically ensures that slavery continues for those convicted of offences (Blackmon, 2009) and, as noted previously, prison labour continues to be used in the US to supplement stretched public services (Nekalson, 2017) or undermine waged labour (Thompson, 2012). Beyond the criminal justice system, contemporary manifestations of slavery and indentured labour are exemplified by temporary ownership and exploitative contractual arrangements within the global economy (Bales, 2005; Picarelli, 2007). Human cargo transforms from property to a disposable commodity. Two centuries after the Abolition Act 1807, the UK government passed the Modern Slavery Act 2015 in recognition of the continuation of trade in human cargo. According to the Global Report on Trafficking in Persons (UNODC, 2016), human trafficking, both within countries, between neighbouring countries and across continents, affect all nations. Women are the predominant victims (Williams, 2011) although sexual exploitation is not the sole motivation. Children are trafficked for numerous reasons (Shen et al., 2013) and men as forced and migrant labour (UNODC, 2016). $88 \%$ of countries have criminalised trafficking yet much of the legislation is recent and the average number of convictions remains low. Papanicolaou (2008) considers the structures of capitalism and its material impact upon national economies and labour 
markets which mirrors and facilitates the exploitation of vulnerable migrants (see Picarelli, 2007).

Poverty, armed conflict, environmental degradation and demographic pressure jettison migrants from their country of origin whilst the financial and political stability of destination countries attract migrants (Antonopoulos and Winterdyk, 2006). Marginalised subjects are expelled within the capitalist dispensation; push factors reflect politico-economic arrangements which exclude and propel bodies across national borders in the hope of refuge and security elsewhere but often resort to dangerous migration decisions and exploitation by unscrupulous traders (UNODC, 2016; also Zizek, 2016). The fundamental gesture at the heart of capitalism is the promise of future satisfaction (McGowan, 2016). The dispossessed subject who seeks to flee from war invests the promise of the future in the West (Zizek, 2016); the insecure and marginalised labourer who seeks economic opportunity invests the promise of the future in overseas labour markets (Antonopoulos and Winterdyk, 2006). The subject who seeks to accumulate further capital and expand Weber's market share invests the promise of the future in trafficking human cargo. Both marginalised victims and perpetrators of human trafficking, invested in the circuits of capitalism and expelled by the politico-ethical ideology of neoliberal polity are driven to attain some future satisfaction which fails to materialise and further stimulates the contemporary trade in human bodies.

While the neoliberal state continues to evidence low growth (Streeck, 2016), legitimate economic opportunities remain restricted to the very high end of the labour market or the low-paid and insecure service and on-demand economy (Lloyd, 2018a). Capitalism continues to generate wealth for the few and exacerbates income inequality (Piketty, 2014). The consolidated state (Streeck, 2016) wedded to deficit reduction and austerity has no capacity (or inclination) to provide a social safety net for those sliding down the slopes of social insecurity. In this context, neoliberalism trades in unproductive bodies, preferring a second negation of punishment. However, a parallel illegal trade in human cargo evidently flourishes (UNODC, 2016) where the marginalised and dispossessed represent productive bodies for those willing to exploit conditions of precarity and insecurity and maximise surplus value. 


\section{Summation and Conclusion}

Geographically and economically the slave trade of the 1700s formed a triangular configuration that exchanged material goods for productive human cargo for profit. This article draws attention to a contemporary triangular trade located within a contingent stream of history and play of forces. We traverse from the earlier trade into the present; from the Keynesian dispensation to its displacement by neoliberal polity. In doing so, we bolt together a triadic geometry of political economy; inequality and social insecurity; the expressive and instrumental reconfiguration of criminal justice. If wealth is sucked up by the vortex of neoliberal capitalism leaving vapour trails of rising inequality; it glides past criminal justice and penal policy heading in the opposite direction toward the lower slope of the socio-economic hierarchy. Furthermore, the tripartite convergence inflicts a double negation of relegation and exclusion. In framing our thesis as a triangular trade we accentuate the new realities of triadic convergence to offer critical insights into political economy and criminal justice practices, legitimised and normalised by a succession of political parties since the 1980 s. Ruskin thought Turner's art contained a revelatory capacity to enhance the scope of human vision, to expose the world in its depths. The contemporary triangular trade in human cargo, juxtaposed with and analytically stimulated by the Atlantic trade, conveys vital and urgent insights into the present. The retinal image of a triangular trade reframes the angle of vision to expose the remaking of political economy from above, the cascading violence of social insecurity, and the new operational logics of criminal justice operating below. If there is any merit in our triadic thesis we cannot remain content with how things have turned out politically, anthropologically, or penologically.

The contemporary trade is not inevitable. What was imposed by political fiat can be reversed. A former Secretary of State at the Ministry of Justice acknowledged that sentences are too long, prisons overcrowded, reconviction rates too high, and the wrong people are currently in prison (Truss, 2017). What is more, a prison population of just under 83,000 in England and Wales is the new politically legitimised normality. Political and media debates continue to espouse law, order and security pronouncements without empirical research to contest and establish new facts. However, history proves that orthodoxy can be challenged and changed: slave traders in the late $18^{\text {th }}$ century had little reason to doubt the 
continuation of their practice; American slaves in the early $19^{\text {th }}$ century would not have expected emancipation in their lifetime; few experts in the 1970s anticipated or predicted the dramatic swing towards penal expansion and mass incarceration from the 1980s onwards. If the triangular slave trade was abolished in unpropitious political, economic, and military circumstances, this is the surface upon which to question the contemporary trade. It is imperative to learn from the historical record which incorporated a response from diverse constituencies including humane sensibilities, moral commitment, and political will. These are not the elemental notes in Foucault's incidental music, but rather the essential components for shaping a new moral, political and penal reality. 


\section{References}

Ackroyd, P., 2006. Brief Lives: J.W.M. Turner, London: Vintage.

Ackroyd, P., 2016. The History of England Volume IV: Revolution, London: Macmillan.

Alexander, M., 2011. The New Jim Crow: Mass Incarceration in the Age of Colour Blindness, New York: The New Press.

Anderson, E., 2000. Code of the Street: Decency, Violence, and the Moral Life of the Inner City, London: W.W. Norton \& Company.

Antonopoulos, G.A. and Winterdyk, J., 2006. "The smuggling of migrants in Greece: An examination of its social organisation", European Journal of Criminology. 3(4) 439-461.

Badiou, A., 2007. The Century, Cambridge: Polity Press.

Bales, K., 2005. Understanding Global Slavery. Berkley: University of California Press.

Baptist, E.E., 2016. The Half Has Never Been Told: Slavery and the Making of American Capitalism, New York: Basic Books.

Baudrillard, J., 2007. In the Shadow of the Silent Majorities, Los Angeles: Semiotext(e).

Bauman, Z., 2004. Wasted Lives: Modernity and its Outcasts, Cambridge: Polity.

Bell, E., 2011. Criminal Justice and Neoliberalism, Houndmills: Palgrave Macmillan.

Blackmon, D.A., 2009. Slavery by Another Name: The Re-enslavement of Black Americans from the Civil War to World War Two, New York: Anchor.

Bourgeois, P., 1995. In Search of Respect: Selling Crack in El Barrio. Cambridge: University Press.

Carter, P., 2007. Securing the Future: Proposals for the Efficient and Sustainable Use of Custody in England and Wales, London: Ministry of Justice.

Cohen, S., 1985. Visions of Social Control: Crime, Punishment and Classification, Cambridge: Polity Press.

Coyle, A., Fair, H., Jacobson, H. And Walmsley, R., 2016. Imprisonment Worldwide: The current situation and an alternative future, Bristol: Policy Press.

Currie, E., 2010. Plain left realism: An appreciation and some thoughts for the future, Crime, Law and Social Change, 54, 111-124.

Dagan, D. and Teles, S., 2016. Prison Break: Why Conservatives Turned Against Mass Incarceration, Oxford: University Press.

Dean, J. 2009. Democracy and Other Neoliberal Fantasies: Communicative Capitalism and Left Politics, London: Duke University Press. 
Drescher, S., 1994. Whose Abolition? Popular pressure and the ending of the British slave trade, Past and Present, 143, 136-166.

Ellis, A., 2016. Men, Masculinities and Violence: An Ethnographic Study, London: Routledge.

Eltis, D. and Engerman, S.L., 2000. The importance of slavery and the slave trade to industrializing Britain, The Journal of Economic History, 60(1) 123-144.

Foucault, M., 1977. Discipline and Punish: The birth of the prison, Harmondsworth: Penguin.

Fuentes, A., 2011. Lockdown High: When the Schoolhouse Becomes a Jailhouse, London: Verso.

Gane, N., 2015. Trajectories of Liberalism and Neoliberalism, Theory, Culture and Society, 32(1) $133-144$

Garland, D., 1990. Punishment and Modern Society: A Study in Social Theory, Oxford and New York: Oxford University Press.

Garland, D., 2001. The Culture of Control: Crime and social order in contemporary society, Oxford and New York: Oxford University Press.

Goldberg, E. and Evans, L., 2003. The Prison Industrial Complex and the Global Economy, Montreal: Kersplebedeb Publishing.

Graham, S., 2011. Cities Under Siege, London: Verso.

Hague, W., 2008. William Wilberforce: The life of the great anti-slave trade campaigner, London and New York: Harper Perennial

Hall, S., et al., 1978. Policing the Crisis: Mugging, Law and Order, and the State, London: Macmillan.

Hall, S., Winlow, S. and Ancrum, C., 2008. Criminal Identities and Consumer Culture, Oxford: Willan.

Harcourt, B.E., 2006. From the asylum to the prison: Rethinking the incarceration revolution, Texas Law Review, 84, 1751-1786.

Harcourt, B.E., 2009. Neoliberal Penality: A Brief Genealogy, John M. Olin Program in Law and Economics Working Paper No. 472.

Harcourt, B.E., 2011. Reducing Mass Incarceration: Lessons from the Deinstitutionalization of Mental Hospitals in the 1960s, Ohio State Journal of Criminal Law, 9(1), 53-88.

Harvey, D., 2005. A Brief History of Neoliberalism, Oxford: University Press.

Harvey, D., 2010. The Enigma of Capital: And the Crises of Capitalism, London: Profile. 
Hinton, E., 2016. From the War on Poverty to the War on Crime: The Making of Mass Incarceration in America, London: Harvard University Press.

Home Office, 1977. A Review of Criminal Justice Policy 1976, London: HMSO.

Horsley, M., 2015. The Dark Side of Prosperity. Farnham: Ashgate.

Horsley, M., 2017. Forget moral panics, Journal of Theoretical and Philosophical Criminology, 9(2) 84-98.

Hough, M., Jacobson, J. and Millie, A., 2003. The Decision to Imprison: Sentencing and the Prison Population, London: Prison Reform Trust.

Lewis, A., 2007. Martin Dockray and the Zong: A Tribute in the Form of a Chronology, Journal of Legal History 28 (3) 357-370.

Lloyd, A., 2013. Labour Markets and Identity on the Post-Industrial Assembly Line, Farnham: Ashgate.

Lloyd, A., 2018a. The Harms of Work: An Ultra-Realist Account of the Service Economy, Bristol: Policy Press.

Lloyd, A., 2018b. "Serving up harm: Systemic violence, transitions to adulthood and the service economy" in Boukli, P. and Kotze, J. (Eds) Zemiology: Reconnecting Crime and Social Harm, Basingstoke: Palgrave Macmillan.

MacLeavy, J., 2010. "Remaking the welfare state: From safety net to trampoline" in K. Birch and V. Mykhnenko (Eds.) The Rise and Fall of Neoliberalism: The Collapse of an Economic Order? London: Zed Books.

Mathiesen, T., 1974. The Politics of Abolition, Martin Robertson.

Mathiesen, T., 2015. The Politics of Abolition Revisited, Abingdon: Routledge.

McGowan, T., 2016 Capitalism and Desire: The Psychic Cost of Free Markets, New York: Columbia University Press.

Merrill, L.T., 1945. The English campaign for the abolition of the slave trade, The Journal of Negro History, 30(4) 382-399.

Miller, D., 2010. “How neoliberalism got where it is: Elite planning, corporate lobbying and the release of the free market" in K. Birch and V. Mykhnenko (Eds.) The Rise and Fall of Neoliberalism: The Collapse of an Economic Order? London: Zed Books.

Millie, A., Jacobson, J. and Hough, M., 2003. Understanding the growth in the prison population in England and Wales, Criminal Justice, 3(4) 369-387. 
Mirowski, P., 2013. Never Let a Serious Crisis Go To Waste: How Neoliberalism Survived the Financial Meltdown, London: Verso.

Mitchell, W. and Fazi, T., 2017. Reclaiming the State: A Progressive Vision of Sovereignty for a Post-Neoliberal World, London: Pluto.

Morris, J., 1979a. Heaven's Command: An imperial progress, volume 1, Harmondsworth: Penguin.

Morris, J., 1979b. Pax Britannica: The climax of an empire, volume 2, Harmondsworth: Penguin.

Nekalson, A., 2017. California is Running Out of Inmates to Fight its Fires, The Atlantic, $\begin{array}{llll}\text { December } & 7^{\text {th }} & \text { 2017, } & \text { Accessed }\end{array}$ https://www.theatlantic.com/politics/archive/2017/12/how-much-longer-willinmates-fight-californias-wildfires/547628/

Padfield, N. and Maruna, S., 2006. The revolving door at the prison gate: Exploring the dramatic increase in prison recalls, Criminology and Criminal Justice, 6(3) 329-352.

Papanicolaou, G., 2008. "The sex industry, human trafficking and the global prohibition regime: A cautionary tale from Greece", Trends in Organised Crime. 11. 379-409.

Parenti, C., 2008. Lockdown America: Police and Prisons in the Age of Crisis, London: Verso.

Parker, M., 2011. The Sugar Barons: Family, corruption, empire and war, London: Hutchison.

Picarelli, J.T., 2007. "Historical approaches to the trade in human beings" in M. Lee (Ed.) Human Trafficking, Cullompton: Willan.

Piketty, T., 2014. Capital in the Twenty-First Century, London: Belknap.

Prison Reform Trust., 2016 summer. Bromley Briefing - Prison Factfile, London: PRT.

Rediker, M., 2008. The Slave Ship: A Human History, London: John Murray.

Reiman, J., 1998. The Rich Get Richer and the Poor Get Prison: Ideology, Class, and Criminal Justice, London and Boston: Allyn and Bacon.

Reiner, R., 2007. Law and Order: An Honest Citizen's Guide to Crime and Control, Cambridge: Polity.

Riello, G., 2013. Cotton: The fabric that made the modern world, Cambridge: Cambridge University Press

Rodger, J.J., 2008. Criminalising Social Policy: Anti-Social Behaviour and the Welfare State in a De-civilised Society, Cullompton: Willan.

Sandel, M., 2012. What Money Can't Buy: The Moral Limit of Markets, London: Allen Lane. 
Shen, A., Antonopoulos, G.A., and Papanicolaou, G., 2013. "China's stolen children: Internal child trafficking in the People's Republic of China", Trends in Organised Crime. 16. 3148.

Sim, J., 2009. Punishment and Prisons: Power and the Carceral State: London: Sage.

Simon, J., 2000. The 'society of captives' in the era of hyper-incarceration, Theoretical Criminology, 4(3) 285-308.

Simon, J., 2014. Mass Incarceration on Trial, London: The New Press.

Smith, O. and Raymen, T., 2016. "Deviant leisure: A criminological perspective", Theoretical Criminology. Online first at http://journals.sagepub.com/doi/full/10.1177/1362480616660188

Sorman, G., 2010. Economics Does Not Lie: A Defence of the Free Market in Times of Crisis, London: Encounter Books.

Streeck, W., 2016. How Will Capitalism End? London: Verso.

Thomas, H., 1998. The Slave Trade: The History of the Atlantic Slave Trade 1440-1870, London: Papermac.

Thompson, H.A. 2010. Why Mass Incarceration Matters: Rethinking Crisis, Decline, and Transformation in Post-War American History, The Journal of American History, 97(3), 703-734.

Thompson, H.A. 2012. The Prison Industrial Complex: A Growth Industry in a Shrinking Economy, New Labor Forum, 21(3), 38-47.

Tonry, M., 1999. Why are US incarceration rates so high? Crime \& Delinquency, 45(4) 419437.

Truss, L., 2017. Views on sentencing and the size of the prison population, Speech to Centre for Social Justice, London.

UNODC, 2016. Global Report on Trafficking in Persons 2016, United Nations Publication.

van der Linden, M., 2010. Unanticipated consequences of 'humanitarian intervention': The British campaign to abolish the slave trade, 1807-1900, Theory and Society, 39(3/4) 281-298.

Varoufakis, Y., 2013. The Global Minotaur: America, Europe and the Future of the Global Economy, London. Zed Books.

Wacquant, L., 2001. Deadly Symbiosis: When Ghetto and Prison Meet and Mesh, Punishment \& Society, 3 (1) 95-134. 
Wacquant, L., 2008. Urban Outcasts: A Comparative Sociology of Advanced Marginality, Cambridge: Polity Press.

Wacquant, L., 2009a. Punishing the Poor: The neoliberal government of social insecurity, Durham and London: Duke University Press

Wacquant, L., 2009b. Prisons of Poverty, Minneapolis: University of Minnesota Press.

Whitehead, P., 2011. Evaluation Report of research at six community chaplaincy projects in England and Wales, Community Chaplaincy Association and Teesside University.

Whitehead, P., 2015a. Reconceptualising the Moral Economy of Criminal Justice, Basingstoke: Palgrave.

Whitehead, P., 2015b. 'Payment by results: the materialist reconstruction of criminal justice', International Journal of Sociology and Social Policy. 35(5/6); 290-305.

Whitehead, P., 2016. Transforming Probation: social theories and the criminal justice system, Bristol: Policy Press.

Whitehead, P., 2018. Demonising the Other: the criminalisation of morality, Bristol: Policy Press.

Whitehead, P. and Crawshaw, P., 2013. Shaking the Foundations: On the Moral Economy of Criminal Justice, British Journal of Criminology 53(4) 588-604.

Williams, E., 1964. Capitalism and Slavery, London: Andre Deutsch.

Williams, P., 2011. "Trafficking in women: The role of transnational organised crime" in Cameron, S. and Newman, E. (Eds.) Trafficking in Humans: Social, Cultural and Political Dimensions, New York: United Nations University Press.

Wilkinson, R. and Pickett, K., 2009. The Spirit Level: Why Equality is Better for Everyone, London: Penguin.

Wilson, W.J., 1997. When Work Disappears: The World of the New Urban Poor, New York: Vintage.

Winlow, S. and Hall, S., 2013. Rethinking Social Exclusion: The End of the Social? London: Sage.

Young, J., 1999. The Exclusive Society, London; Sage.

Young, J., 2007. The vertigo of late modernity, Thousand Oaks: Sage.

Žižek, S., 2016. Against the Double Blackmail: Refugees, Terror and Other Troubles with the Neighbours, London: Allen Lane. 
